УДК 616.31-089.444

DOI 10.11603/2411-1597.2020.4.11877

\title{
ШТУЧНА ВЕНТИЛЯЦІЯ ЛЕГЕНЬ. МЕТОДИКА ПРОВЕДЕННЯ ШТУЧНОЇ ВЕНТИЛЯЦІї ЛЕГЕНЬ ТА ЇЇ ФУНКЦІї
}

\author{
В. С. Тіторчук, У. О. Наумова \\ Тернопільський національний медичний університет \\ імені І. Я. Горбачевського МОЗ України
}

У статті представлено різні методики проведення штучної вентиляції легень та їх значення в лікуванні та підтримці життедіяльності організму людини.

\section{ARTIFICIAL LUNG VENTILATION. METHODS OF ARTIFICIAL LUNG VENTILATION AND ITS FUNCTIONS}

\author{
V. S. Titorchuk, Y. O. Naumova \\ I. Horbachevsky Ternopil National Medical University
}

The article presents various methods of artificial lung ventilation and their importance in the treatment and maintenance of the human body vital functions.

Вступ. Одним з головних завдань відділення анестезіології та інтенсивної терапії $є$ анестезіологічне забезпечення оперативних втручань та діагностичних досліджень. Відділення анестезіології та інтенсивної терапії приймає тяжкохворих пацієнтів з усіх інших відділень лікарні, в тому числі хворих із декомпенсованим цукровим діабетом, гострим та хронічним панкреатитом, холециститом, новоутвореннями будь-якого органа або системи, тяжкими інфекційними процесами та сепсисом, хворих із небезпечними травмами, гострими порушеннями мозкового кровообігу (інсультами), інфарктом міокарда, серцевою та дихальною недостатністю тощо. Завдяки цілодобовому спостереженню та лікуванню, госпіталізовані хворі отримають найбільш повний спектр допомоги та догляду. Відділення інтенсивної терапії має в своєму розпорядженні широкий спектр засобів для оперативної та точної діагностики з подальшим проведенням належного лікування. Сюди входять діагностичні та лікувальні засоби, в тому числі сучасні апарати для штучної вентиляції легень (ШВЛ) із режимом неінвазивної вентиляції, які використовують для підтримки життєдіяльності організму людини [1].

Основна частина. Апарати штучної вентиляції легень відіграють важливу роль у порятунку пацієнтів () В. С. Тіторчук, У. О. Наумова, 2020 із тяжкою формою захворювання - таких пацієнтів підключають до апаратів ШВЛ для забезпечення достатнього надходження кисню. За даними Міністерства охорони здоров'я, в Україні $є$ наразі близько 3,5 тис. апаратів штучної вентиляції легень, що допомагають у лікуванні хворих, які цього потребують. За підрахунками проекту з контролю публічних закупівель DOZORRO, з 1 січня до 28 березня державні структури закупили через Prozorro 385 апаратів штучної вентиляції легень на понад 286 млн грн. Найбільше ШВЛ через Prozorro придбали в Дніпропетровській (79), Київській (71), Херсонській (33) та Львівській (31) областях, найменше - у Рівненській, Івано-Франківській та Запорізькій. Там закупили лише по одному апарату. Важливо розуміти, що це не всі закупівлі апаратів штучної вентиляції легень для українських лікарень. Частину апаратів ШВЛ зараз купують приватним коштом. В Україні немає власного виробництва ШВЛ, тож усіх їх доставляють з-за кордону. Вони бувають різних типів. Тому і коштувати шВЛ можуть від 25 тис. грн до 1-2 млн. Найдешевші - це ті, якими обладнують машини швидкої допомоги, а найдорожчі - стаціонарні апарати з інтелектуальним керуванням. Найдорожчі апарати ШВЛ закупили у Запорізькій (2,4 млн грн), Донецькій (1,16 млн грн) та Дніпропетровській (943 тис. грн) областях. За інформа- 
цією Міністерства охорони здоров'я України, у 240 лікарнях є 1882 апарати штучної вентиляції легень. Усього в країні, за даними МО3, є близько 4000 ШВЛ. Віднедавна державним структурам стало простіше закупляти лікарські засоби, засоби індивідуального захисту та медичного обладнання (зокрема апарати шВЛ). Відповідно, медичні заклади та інші державні установи за один день можуть провести закупівлю необхідних товарів у обраного постачальника, а далі лише прозвітувати про цю закупівлю в системі Prozorro. 3 одного боку, це дасть змогу державним структурам максимально швидко купувати ліки та медичні вироби за умов дефіциту товарів на ринку, з іншого - всі ці витрати будуть прозорими і дадуть змогу громадськості та контролюючим органам перевіряти можливі факти переплати.

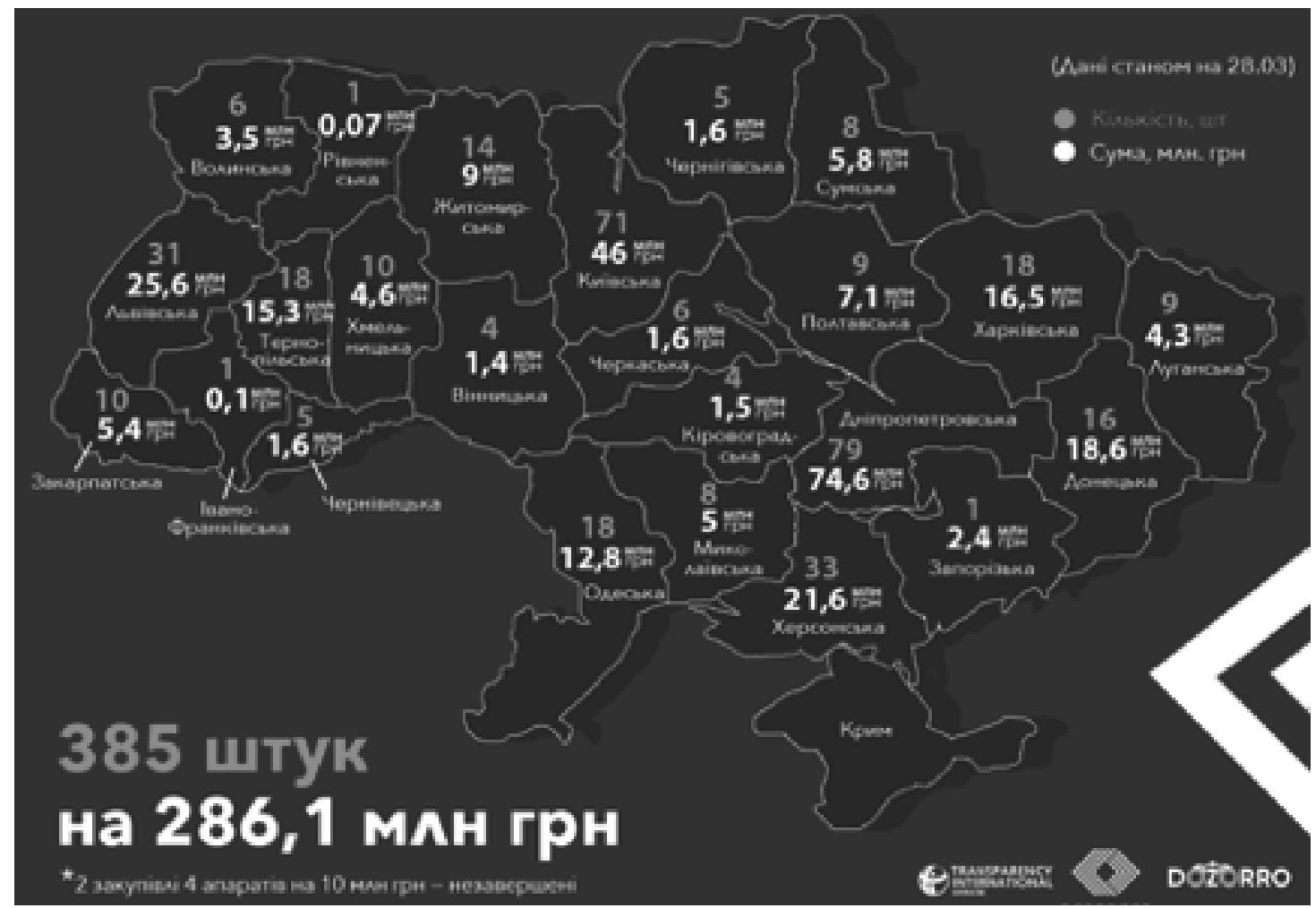

Хто ж першим винайшов ШВЛ і які методики та апарати використовували для підтримки життєдіяльності організму людини? [2].

У кінці 50-х років XX століття американський медик Пітер Сафар запропонував комплекс серцево-легеневої реанімації (СЛР), принципи та методи проведення цих заходів постійно вдосконалювали та переглядали. До цього постраждалих рятували народними методами: прикладали до тіла гаряче вугілля, тягали на лямках чи скручували в «бублик». Київська «Швидка допомога» теж мала власний метод. За правилами початку XX століття, коли людина переставала дихати, лікар хапав ії за язик, витягував його і давав тримати помічникові. А сам то підіймав лікті постраждалого вгору, то знову притискав їх до грудей - часто протягом двох-трьох годин. Таким чином, інколи вдавалося врятувати недужих (як записано у щорічному звіті 1903 р.). До 60-х років минулого століття широко були розповсюджені методи штучного дихання за допомогою рук - метод Сильвестра (рис. 1) і Шефера (рис. 2), Говарда-Томсона, Емерсона, Холгор-Нільсена (рис. 3), Калістові. Перелічені методи визнані малоефективними і їх потрібно застосовувати лише тоді, коли рятувальник не може застосувати більш ефективні методи (у випадку особливо небезпечних інфекцій, отруєння фосфорорганічними сполуками, тяжкої травми обличчя). Та й на сьогодні, якщо $€$ висока небезпека заразитися від постраждалого інфекційними хворобами, і немає спеціального клапана, у крайньому разі можна застосувати так звані ручні способи реанімації. Скажімо, метод Сильвестра: максимально розводять і зводять руки, енергійно натискаючи на нижню частину грудної клітки. Втім, ефект від цієї процедури значно нижчий [3].

Показання до проведення негайної штучної вентиляції поділяють на абсолютні (апное, патологічні типи дихання, гіповентиляція) та відносні (набряк легень, глибока кома, декомпенсована циркуляторна, 


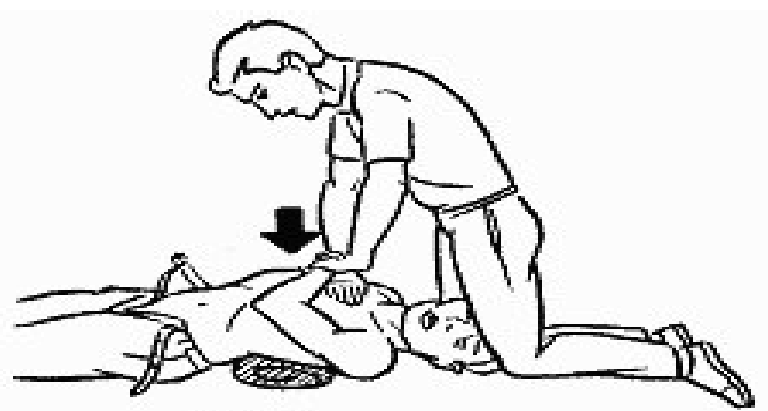

видих

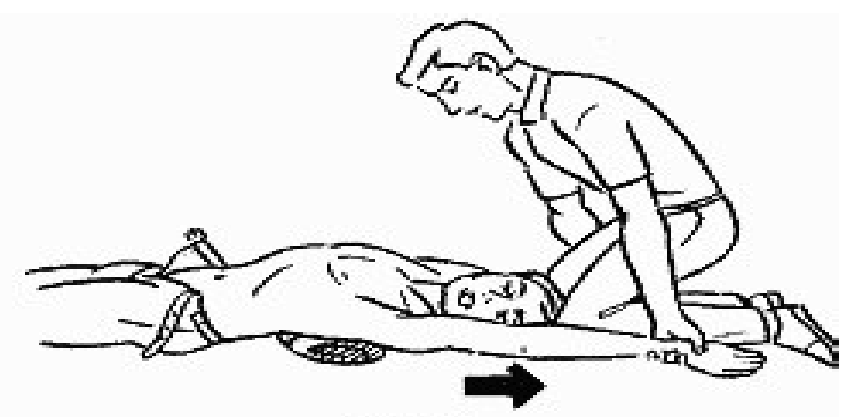

вдих

Рис. 1. Метод Сильвестра.

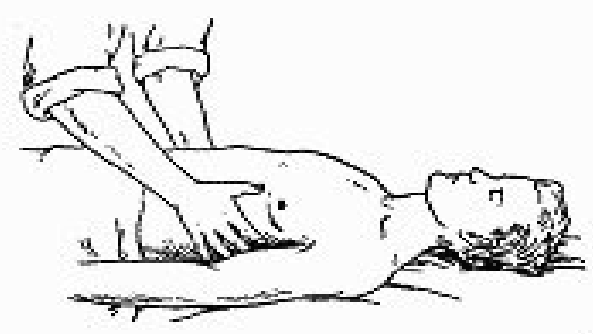

видих

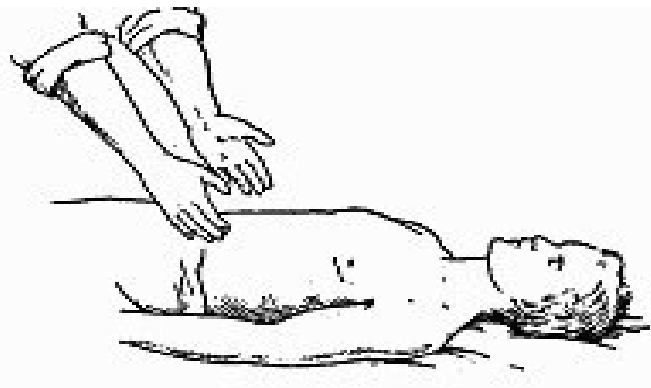

вдих

Рис. 2. Метод Шефера.

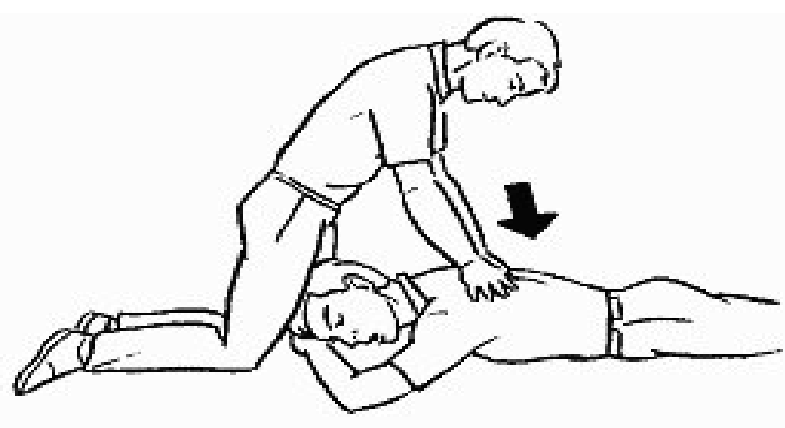

видих

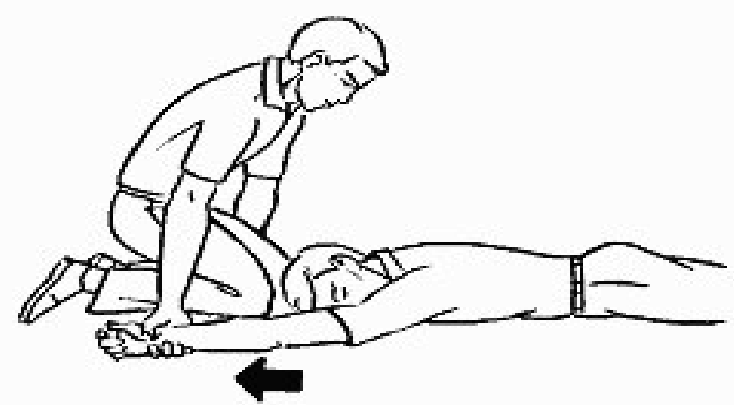

вдих

Рис. 3. Метод Холгор-Нільсена.

кардіальна чи дихальна недостатність). Проводити цю маніпуляцію можна такими методами: рот до рота; рот до носа; з рота в рото- або носоглотковий повітровід; через маску (з рота в маску) або в інтубаційну трубку (з рота в трубку); за допомогою ручних дихальних апаратів, мішка Амбу; з використанням автоматичних дихальних апаратів. В екстрених умовах найчастіше використовують штучне дихання способом «рот до рота» або «рот до носа» [4].

Методика проведення штучної вентиляції легень:

1. Покласти постраждалого спиною на рівну поверхню.

2. Очистити ротову порожнину від слизу, згустків крові, блювотиння.

3. Якщо немає черепно-мозкової травми, відвести голову постраждалого максимально назад і висунути його нижню щелепу вперед і вгору, натиснувши двома пальцями нижче вух (прийом Сафара). Якщо це не привело до відновлення самостійного дихання, зробити штучну вентиляцію легень методом «рот до рота» (рис. 4).

4. Підтримуючи однією рукою нижню щелепу постраждалого, затиснути йому ніздрі. Глибоко вдихнувши, щільно обхопити губами рот хворого.

5. Вдувати повітря потрібно 15-16 разів на хвилину. Комбінувати штучне дихання та непрямий масаж серця необхідно так: 2 вдихи - 15 натискань. Якщо реанімацію проводять двоє людей, то перший робить один вдих, а інший 5 натискань.

6. За правильного проведення реанімації грудна клітка постраждалого під час вдування піднімається, а потім опускається; при цьому з його рота відчувається 
потік повітря. Ефекту від штучної вентиляції легень не буде, якщо немає герметичності: повітря виходитиме у щілину між ротами постраждалого й рятівника.

7. Вдих одночасно роблять і в рот, і в ніс, якщо реанімують дитину, або у дорослого $\epsilon$ травми рота, міцно стиснуті щелепи.

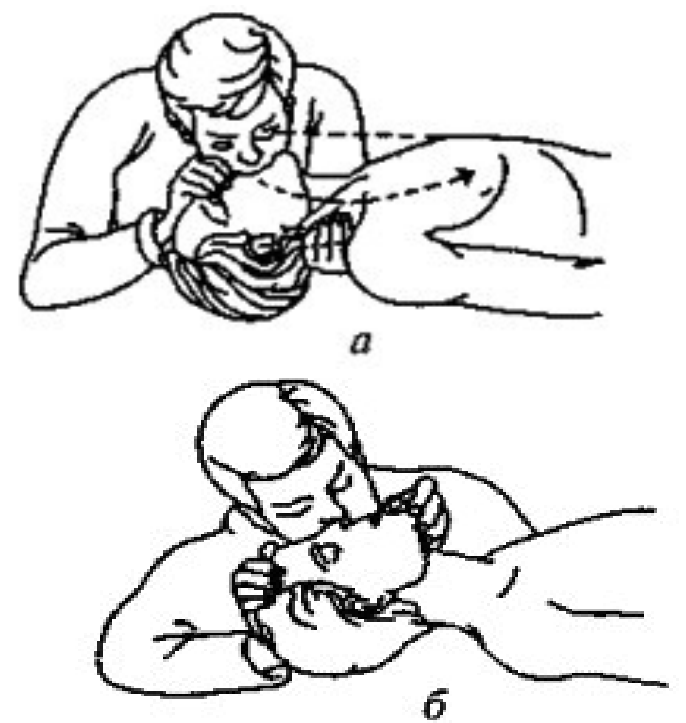

PUс. 4. Методи штучного дихання: а - рот до рота; 6 - рот до носа.

Метод «рот до носа» - принцип полягає в тому, що рятувальник вдуває повітря не через рот, а через ніс постраждалого (рис. 4 б). Цей метод застосовують тоді, коли з певних причин неможливо застосувати метод «рот до рота» (неможливо відкрити нижню щелепу, при пораненні губ, язика). Техніка виконання: однією рукою, яку кладуть на чоло постраждалого, закидають йому голову, іншою, піднімаючи його підборіддя і нижню щелепу, закривають рот. Вдування повітря виконують через носові ходи. У період пасивного видиху необхідно трохи відкрити рот постраждалого. Потім вдування продовжують в тому ж ритмі. Ефективність вдування повітря оцінюють за ступенем дихальних екскурсій грудної клітки. Методика штучного дихання «рот до рота» або «рот до носа» передбачає: закидування голови (при підозрі на перелом або вивих у шийному відділі хребта гіперекстензію не дозволяють), висування нижньої щелепи уперед, розтулювання рота - потрійний прийом Сафара для відновлення прохідності верхніх дихальних шляхів. ШВЛ «рот до носа» проводять в таких випадках: при ушкодженні губ, нижньої щелепи, язика; коли неможливо досягти герметизації під час дихання «рот до рота»; коли неможливо розсунути щелепи. Штучну вентиляцію легень проводять за допомогою повітровода (рис. 5):
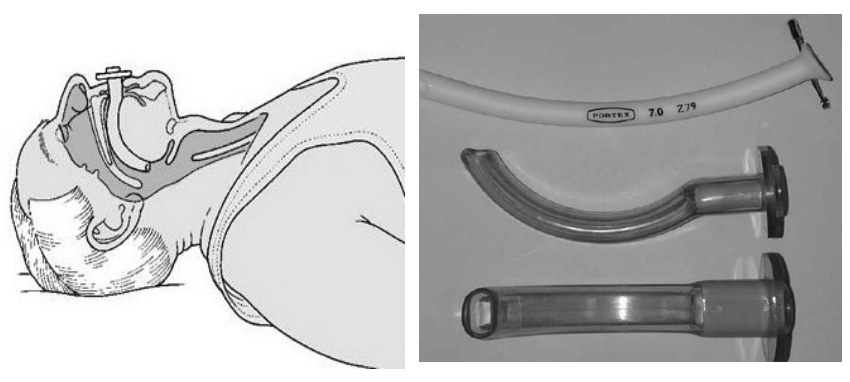

PUC. 5. Штучна вентиляція легень за допомогою повітровода.

1. Візьміть повітроводи, серветки, лейкопластир.

2. Покладіть хворого на спину.

3. Станьте від хворого збоку біля голови.

4. Закиньте голову хворого назад і відкрийте ротову порожнину.

5. Очистіть ротову порожнину за допомогою марлевої серветки.

6. Підберіть потрібний повітровід, що дорівнює відстані від кута рота до кута нижньої щелепи.

7. Станьте біля голови хворого позаду.

8. Введіть повітровід увігнутою поверхнею по ходу язика до його кореня.

9. Великими пальцями притисніть щиток до губ постраждалого, а вказівними пальцями виведіть нижню щелепу вперед.

10. Закріпіть повітровід лейкопластиром або бинтом.

11. Зробіть глибокий вдих, а потім видих у повітровід.

12. Продовжуйте маніпуляцію до відновлення самостійного дихання з частотою 12-15 разів на хвилину.

Штучна вентиляція легень за допомогою мішка Амбу (рис. 6 ).

Методика проведення:

1. Візьміть мішок Амбу.

2. Покладіть хворого на кушетку.

3. Станьте біля голови хворого позаду.

4. Закиньте однією рукою голову хворого назад.

5. Щільно притисніть маску до обличчя.

6. Тягніть підборіддя хворого 1-3 пальцями вгору.

7. Іншою рукою витисніть повітря з мішка Амбу.

8. Повторюйте маніпуляцію до появи самостійного дихання з частотою 12-15 разів на хвилину. При стисканні мішка повітря з нього нагнітається в дихальні шляхи постраждалого. Видих проходить через спеціальний клапан, при цьому балон (мішок) розправляється самостійно. 


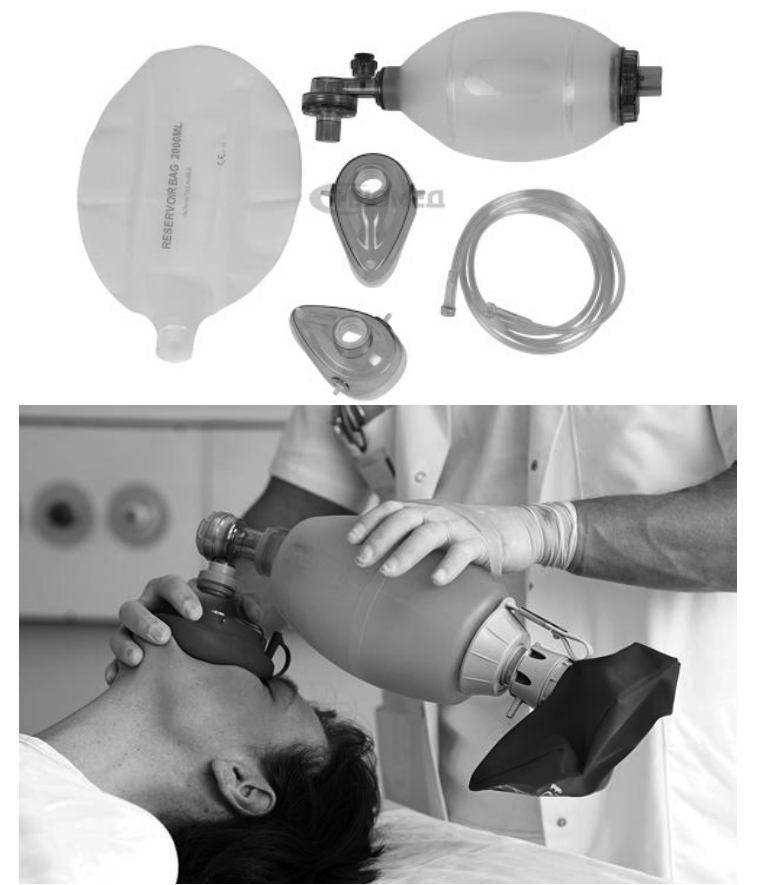

Puc. 6. Штучна вентиляція легень за допомогою мішка Амбу.

Штучна вентиляція легень через інтубаційну трубку (рис. 7). Техніка виконання (інтубація через рот).

1. Перевірте манжету ендотрахеальної трубки: введіть повітря (приблизно 10 мл), якщо манжета ціла, перед введенням видаліть повітря.

2. Перевірте ларингоскоп - чи підходить клинок, чи горить лампочка.

3. Проведіть преоксигенацію через маску.

4. Видаліть ротовий повітровід, якщо він встановлений.

5. Відкрийте рот пацієнта правою рукою; якщо він у свідомості, попросіть відкрити рот якомога ширше.

6. Візьміть ларингоскоп у ліву руку.

7. Обережно введіть клинок ларингоскопа у ротову порожнину, не торкаючись зубів (можливе ушкодження).

8. Введіть клинок по спинці язика, поки не відкриється голосова щілина.

9. Розташуйте кінець клинка: якщо це вигнутий клинок - між коренем язика та надгортанником, піднімаючи корінь язика, виводять гортань, голосові зв'язки та проводять інтубацію трахеї інтубаційною трубкою зі здутою манжетою за голосові зв'язки; якщо це прямий клинок - захоплюють надгортанник, виводять голосові зв'язки і проводять інтубацію трахеї (надгортанник притискають до верхньої стінки ротоглотки та таким чином візуалізуються зв'язки; цей метод вважають більш травматичним порівняно з використанням косого клинка).
10. Зафіксуйте ліве зап'ястя, підніміть рукоятку ларингоскопа до уявного орієнтира над лівою ступнею пацієнта для звільнення голосових зв'язок. Уникайте надлишкових рухів у лівому зап'ястку назад і нагору, щоб попередити ушкодження зубів.

11. Введіть інтубаційну трубку зі здутою манжеткою по вигину клинка ларингоскопа; заведіть манжету за голосові зв'язки, після чого помічник витягує зонд (провідник, стилет) з інтубаційної трубки. Не вводьте трубку глибоко у трахею з провідником.

12. Роздуйте манжету повітрям (5-10 мл).

13. Зафіксуйте трубку.

14. При можливості приєднайте монітор для визначення $\mathrm{pCO}_{2}$ у повітрі, що видихає пацієнт.

15. Спостерігайте за рухами грудної клітки.

16. Вимірюйте $\mathrm{pCO}_{2}$ у видихуваному повітрі як мінімум протягом дихальних рухів - саме так можна пересвідчитися, що видихуване повітря надходить 3 легень, а не з роздутого при інтубації шлунка.

17. Проведіть аускультацію легень з двох сторін. Перед аускультацією необхідно пересвідчитися, чи не потрапляє повітря у шлунок. Для цього розмістіть фонендоскоп у ділянці шлунка (наявність булькотіння свідчить про неправильне розміщення ендотрахеальної трубки).

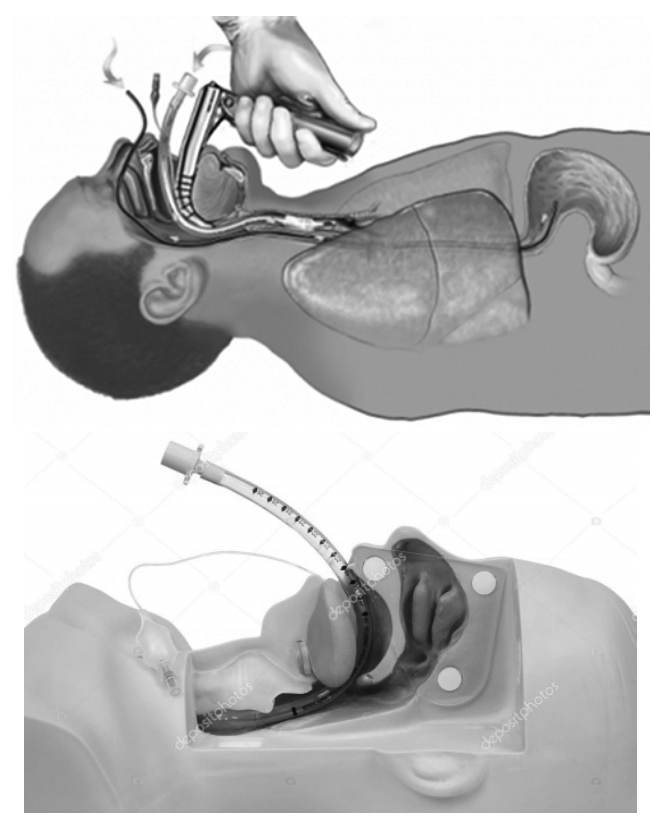

Puc. 7. Штучна вентиляція легень через інтубаційну трубку.

18. Пам'ятайте! Частою помилкою $є$ недостатнє відкриття рота, що поряд з утрудненням проведення ларингоскопії підвищує ризик ушкодження язика: огляд голосових зв'язок легко виконують за допомогою прямого клинка Міллера, при цьому введення 
ендотрахеальної трубки утруднено, для цього відтягують правий кут рота і переміщують ендотрахеальну трубку від правих молярів ближче до центру.

Спрощена процедура підключення пацієнта до апарата оптимізує роботу лікаря, а кнопки прямого доступу дають змогу оперативно реагувати на зміни стану пацієнта. Апарати підтримують значну кількість режимів вентиляції, включаючи інвазивний і неінвазивний, що дозволяє підібрати оптимальний варіант, виходячи з конкретної клінічної ситуації. Відповідно, апарат ШВЛ найчастіше використовують для інвазивної вентиляції легень - через інтубаційну трубку, введену до дихальних шляхів пацієнта або через трахеостому (рис. 8 ).
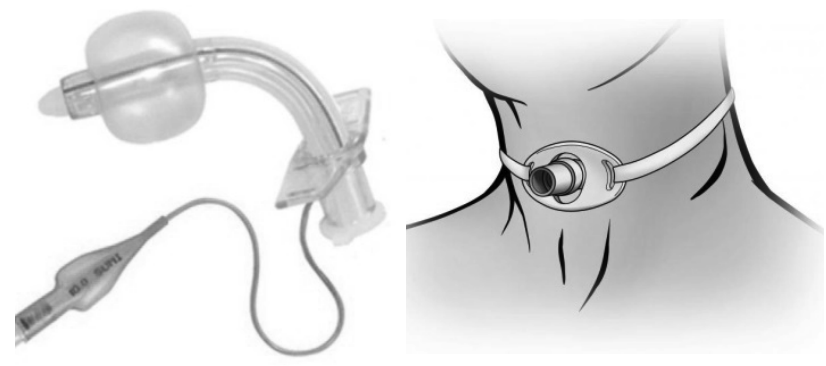

Pис. 8. трахеостомічна трубка.

При проведенні апаратної ШВЛ, вибір параметрів здійснюють за загальноприйнятою методикою. Дихальний об'єм залежить від віку та конституції хворого, його вираховують за формулою: для новонароджених - 10,0-12,0 мл/кг; для дітей старшого віку та дорослих - 8,0-10,0 мл/кг. Критерієм достатності ШВЛ $\epsilon$ синхронізація хворого з апаратом без застосування седативних та пригнічувальної дії на центральну нервову систему засобів. Частота швл: для дітей: новонароджених - 40-60 разів на 1 хв; молодшого віку - 30 разів на 1 хв; старшого віку - 20-24 рази на 1 хв; для дорослих: 12-20 разів на 1 хв. Найточнішим показником достатньої вентиляції $є$ реєстрація газів крові [5]. Штучну вентиляцію легень поділяють на тривалу та короткотривалу. Повітря при тривалій ШВЛ повинно обов'язково зволожуватись та підігріватись. Крім цього, численні дослідженні останніх років продемонстрували ефективність так званої «протекторної» ШВЛ, яка полягає в застосуванні низьких дихальних об'ємів та низького насичення газової суміші киснем. Такий підхід значно зменшує частоту вентилятор-індукованого гострого ушкодження легень та тривалість ШВЛ, покращує виживання пацієнтів [6]. Іншою особливістю тривалої швЛ $\epsilon$ те, що ії можна проводити як через ендотрахеальну трубку (так само, як і короткотривалу), так і через трахеостому. Трахео- стомію виконують у випадку, якщо ШВЛ проводять (або планують їі проведення) протягом 10-14 і більше днів. Так, наприклад, у США тривалою вважають вентиляцію, яку проводять більше 6 год на добу і не менше 21 дня поспіль. Однак, таке визначення зумовлено особливостями фінансування цього втручання, а не медичними відмінностями. Більшість фахівців вважає тривалою ШВЛ ту, яку проводять більше 1-3 діб. Велике значення в успішному проведенні тривалої швл мають такі, на перший погляд, дрібниці, як положення пацієнта у ліжку, застосування і регулярна заміна бактеріальних фільтрів, проведення фізичних вправ, періодичний туалет дихальних шляхів і видалення секрету тощо.

Апарати для штучної вентиляції легень (вентилятори) також найчастіше використовують під час великих операцій, коли необхідно максимально розслабити м'язи пацієнта, що призводить також до розслаблення дихальних м'язів і неможливості самостійного дихання у хворого (тобто під час наркозу). Звичайно, це короткотривала штучна вентиляція легень. Але, крім цього, вентилятори застосовують у випадках, коли самостійне дихання пацієнта не забезпечує адекватного надходження кисню до організму і видалення з нього вуглекислого газу (пневмонії, гострий респіраторний дистрес-синдром, серцева недостатність та ін.) або існує ризик, що у пацієнта в будь-який момент може відбутись зупинка дихання (кома). Часто це тривала ШВЛ. Апарати для інгаляційного наркозу призначені для подання інгаляційної анестезії під час хірургічних втручань. Апарати високого класу забезпечать не тільки анестезію, але й респіраторну підтримку в найближчий післяопераційний період, полегшать процес відновлення спонтанного дихання. Також забезпечує отримання газонаркозної суміші з точною концентрацією анестетиків та підтримання в ній оптимального співвідношення кисню та вуглекислого газу. Для запобігання виникненню перехресних інфекцій, абсорбер піддається стерилізації в автоклаві. Тому ШВЛ має широке значення в лікуванні та підтримці життєдіяльності організму людини.

Висновки. Апарати штучної вентиляції легень - це високотехнологічне медичне обладнання для примусової подачі газової суміші (кисень і стиснуте осушене повітря) в легені для насичення крові киснем і видалення з легень вуглекислого газу, які використовують у відділенні анестезіології та інтенсивної терапії. Також існують різні методи проведення ШВЛ: рот до рота, рот до носа, через носоглотковий повітровід, через

60 ISSN 2411-1597. МЕДСЕСТРИНСТВО. 2020. № 4 
маску (з рота в маску) або в інтубаційну трубку; за допомогою ручних дихальних апаратів; мішка Амбу; з використанням автоматичних дихальних апаратів.

\section{СПИСОК ЛІТЕРАТУРИ}

1. Іванюшко В. Анестезія та інтенсивна терапія : навч. посіб. для лікарів-інтернів за фахом «Анестезіологія» / В. Іванюшко, Й. Канюк. - Львів : Каменяр. - 2005. - 285 с. 2. Усенко Л. В. Посібник з практичних занять з анестезіології та реаніматології ; за ред. Л. В. Усенко. - К. : Здоров'я. - 1993. - 320 с.

3. Чепкий Л. П. Анестезіологія, реаніматологія та інтенсивна терапія : підручник / Л. П. Чепкий, Л. В. НовицькаУсенко, Р. О. Ткаченко. - К. : Вища школа, 2003. - 399 с.

4. Ефективність, безпечність і переносимість неінвазивної штучної вентиляції легень при позагоспітальній
Своєчасне підключення до апарату ШВЛ максимально збільшує шанси пацієнта вижити.

пневмонії (обсерваційне дослідження) / Р. Р. Волощук, Я. М. Підгірний, О. П. Закотянський та ін. // Медицина невідкладних станів. - 2011. - № 7-8 (38-39). - С. 156-159.

5. Мавродий В. М. Справочник по неотложной и интенсивной терапии. Программы успешной практики для грамотных врачей / В. М. Мавродий. - 5-е изд., перераб. и доп. - К. : Заславский А. Ю, 2016. - 581 с.

6. Анестезіологія та інтенсивна терапія : підручник / Ф. С. Глумчер, Л. П. Чепкий, Л. В. Новицька-Усенко та ін. ; за ред. Ф. С. Глумчера. - К. : ВСВ «Медицина», 2020. - 360 с.

Отримано 01.12.20 